\title{
MENINGKATKAN KEMAMPUAN MEMBACA PERMULAAN MELALUI MEDIA PAPAN LOTTO PADA KELOMPOK A1 DI RA ANNUR WONOAYU SIDOARJO
}

\author{
Ani Sriningsih, Sunanto, Berda Asmara, Fifi Khoirul Fitriyah \\ Prodi Pendidikan Guru Pendidikan Anak Usia Dini, Universitas Nahdlatul Ulama, Surabaya, \\ Indonesia
}

\section{Info Articles}

\section{Sejarah Artikel:}

Disubmit 27 Januari 2022

Direvisi 30 Januari 2022

Disetujui 31 Januari 2022

Keywords:

beginner, Lotto board media
Improve, Ability, Reading for

\begin{abstract}
Abstrak
Latar Belakang penelitian ini dengan adanya permasalahan anak kelompok A1 di RA ANNUR Wonoayu Sidoarjo yang mengalami kesulitan dalam minat belajar membaca permulaannya masih kurang. Anak usia dini, merupakan anak yang berada pada rentang usia 0-6 tahun, yang memiliki rasa peka dan penting bagi anak untuk mendapat pendidikan yang sering disebut masa golden age. Dengan metode papan lotto, anak akan belajar mengenal huruf dan cara membacanya dengan benar.Tujuan dari penelitian ini adalah untuk menganalisis kesulitan anak dalam membaca permulaan melalui media papan lotto dan memotivasi anak agar mampu mengenal konsep huruf yang benar. Metode penelitian data yang di pakai penelitian ini diperoleh dari observasi dan dokumentasi anak kelompok A1 yang berjumlah 20 anak. Kemudian data dikumpulkan sehingga menjelaskan temuan dan didapat kesimpulan akhir.Hasil penelitian ini berdasarkan penelitian yang dilakukan mendapatkan hasil kemampuan membaca permulaan anak sebesar 48,8\% dengan rata-rata 1,46 dengan kriteria mulai berkembang, $71,1 \%$ dengan rata-rata 2,31 dengan kriteria berkembang sesuai harapan, dan $90,55 \%$ dengan rata-rata 2,71 dengan kriteria berkembang sangat baik. Simpulan secara umum, penelitian yang dilakukan untuk menganalisis minat belajar membaca permulaan anak kelompok A1 terdapat kesimpulan akhir berada pada kategori tergolong dengan kriteria berkembang sangat baik.
\end{abstract}

\section{Abstract}

The background of this study is there is a problem with children in group A1 at RA ANNUR Wonoayu Sidoarjo who have difficulty in learning to read at first. Early childhood children who are in the age range 0-6 years, have a good sensitivity, it is important for them to get an education in this era, which is often called the golden age. With the lotto board method, children will learn to recognize letters and how to read them correctly.The purpose of this study was to analyze the difficulties of children in early reading through the lotto board media and to motivate them to be able to recognize the correct letter concept. The data collected by usingobservation and documentation of group A1 children with total 20 children. The data is collected to explain the findings and a final conclusion is obtained. The results of this study based on research conducted to get the results of the child's early reading ability of $48.8 \%$ with an average of 1.46 with criteria starting to develop, $71.1 \%$ with an average of 2.31 with criteria developing as expected, and $90,55 \%$ with an average of 2.71 with very well-developed criteria. In general, the research conducted to analyze the interest in learning to read at the beginning of the children in group A1 found that the final conclusion was that they were in the very well-developed category.

Alamat Korespondensi:
E-mail: anisriningsih107.tk17@student.unusa.ac.id




\section{PENDAHULUAN}

Anak usia dini merupakan anak yang berada pada rentang usia 0 sampai 6 tahun yang memiliki rasa peka dan penting bagi anak untuk mendapatkan pendidikan Depdiknas (2010:1). Pengalaman yang diperoleh anak dan lingkungan, termasuk stimulasi yang diberikan oleh orang dewasa, akan mempengaruhi kehidupan anak dimasa yang akan datang. Oleh karena itu diperlukan upaya yang mampu memfasilitasi anak dalam masa tumbuh kembangnya berupa kegiatan pendidikan dan pembelajaran sesuai dengan usia, kebutuhan dan minat anak. Maimunah Hasan (2012:15) mengungkapkan bahwa Pendidikan anak usia dini merupakan salah satu bentuk penyelenggaraan pendidikan yang menitik beratkan pada: 1) Pertumbuhan dan perkembangan fisik (koordinasi motorik halus dan kasar); 2) Kecerdasan (daya pikir, daya cipta, kecerdasan emosi, kecerdasan spiritual); 3) Sosioemosional (sikap dan perilaku serta agama) bahasa komunikasi, yang disesuaikan dengan keunikan dan tahap-tahap perkembangan yang dilalui oleh anak usia dini

Menurut Y.N. Sujiono (2009:45) Berdasarkan Undang-undang No 20 Tahun 2003 tentang Sistem Pendidikan Nasional Pasal 28 tentang Pendidikan Anak Usia Dini bahwa penyelenggaraan pendidikan anak usia dini dapat melalui jalur formal, non formal dan informal. Pendidikan formal usia dini 3 jalur ini berbentuk dalam Taman Kanak-Kanak (TK), Raudhatul Athfal (RA),atau bentuk pendidikan lainnya yang sederajat. Pendidikan nonformal berbentuk Kelompok Bermain (KB), Tempat Penitipan Anak (TPA), maupun bentuk pendidikan nonformal lainnya yang sederajat. Pendidikan informal dalam bentuk pendidikan keluarga yang pada dasarnya meliputi seluruh tindakan pendidikan yang dilakukan oleh pendidik serta keluarga dalam mendidik anak. Maimunah Hasan (2012:15-17) mengungkapkan bahwa tujuan diselenggarakannya pendidikan anak usia dini, yaitu: 1) Membentuk anak Indonesia yang berkualitas, yaitu yang tumbuh dan berkembang sesuai dengan tingkat perkembangannya, sehingga memiliki kesiapan yang optimal di dalam memasuki pendidikan dasar serta mengarungi kehidupan di masa dewasa; 2) Membantu menyiapkan anak mencapai kesiapan belajar di sekolah

Membaca sangat penting dalam kehidupan manusia. Tidak ada kegiatan yang tidak memerlukan membaca. Dengan membaca, manusia dapat memahami banyak hal. Membaca juga merupakan model untuk mempelajari ilmu-ilmu lain. Untuk itu, manusia perlu memiliki kemampuan membaca. Dengan perkembangan teknologi informasi menuntut dukungan budaya baca tulis. Budaya baca harus mulai di pupuk sejak dini. Akan tetapi, yang menjadi pertanyaan sekarang, kapan kemampuan membaca dan menulis itu mulai dianjurkan? Jawaban pertanyaan ini sebenarnya masih dalam polemik. Ada sebagian pendapat yang menyatakan bahwa membaca dan menulis baru dianjurkan pada saat anak sudah di SD, tetapi banyak juga ahli yang mengatakan bahwa membaca dan menulis harus di stimulasi sejak dini.

Berdasarkan observasi awal, Peneliti menemukan permasalahan. Permasalahannya yaitu rendahnya minat peserta didik belajar membaca permulaan. Dari observasi awal di temukan pada kelompok A1 dengan jumlah 15 anak, yang bermasalah dengan belum mengenal huruf A-Z ada 10 anak dan yang sudah mengenal huruf A-Z hanya ada 5 anak. Dengan metode papan lotto, anak akan belajar mengenal huruf dan cara membacanya, Selain itu pada saat bermain fantasi atau imajinasi yang dimiliki anak TK/RA dapat berkembang. Anak akan reflek menyampaikan hasil pemikirannya, baik dalam bentuk bahasa, motorik, dan hasil karya atau ciptaannya

Berdasarkan uraian diatas dan melihat karasteristik anak TK/RA yang masih suka bermain, maka peneliti akan mencoba menggunakan media pembelajaran dengan papan lotto, dengan tujuan untuk meningkatkan kemampuan membaca permulaan dan memudahkan anak untuk mengenal dan memahami serta mengerti urutan huruf (A-Z). Yang diharapkan dapat membantu guru menciptakan suasana belajar mengajar dengan bermain yang menarik dan menyenangkan bagi anak. Dari hasil observasi tersebut guru berupaya untuk menuntaskan pembelajaran dalam membaca permulaan dengan melakukan penelitian tindakan kelas yang berjudul "Meningkatkan Kemampuan Membaca Permulaan Melalui Media Papan Lotto", sebagai upaya meningkatkan 
keaktifan anak, yang berdampak positif terhadap peningkatan hasil bermain sambil belajar untuk anak usia dini

\section{METODE}

Penelitian ini menggunakan penelitian tindakan kelas (PTK). Menurut Arikunto (2012:3) Penelitian Tindakan Kelas atau PTK merupakan suatu pencermatan terhadap kegiatan belajar berupa suatu tindakan yang sengaja dimunculkan dan terjadi dalam sebuah kelas secara bersama. Menurut Sa'dun Akbar (2009:26) menjelaskan PTK yaitu proses investigasi terkendali untuk menemukan dan memecahkan masalah pembelajaran di kelas, proses pemecahan masalah tersebut dilakukan secara bersiklus, dengan tujuan untuk meningkatkan kualitas pembelajaran dan hasil pembelajaran di kelas tertentu. Menurut Burhan (2013:3) berpendapat bahwa penelitian tindakan kelas adalah penelitian praktis yang dimaksudkan untuk memperbaiki pembelajaran di kelas. Dari paparan para ahli diatas dapat disimpulkan bahwa penelitian tindakan kelas merupakan suatu pencermatan terhadap kegiatan belajar yang dimaksudkan untuk memperbaiki pembelajaran di kelas dan meningkatkan kualitas tindakan di dalamnya. Penelitian Tindakan Kelas (PTK) menggunakan model Arikunto. Konsep pokok penelitian tindakan model Arikunto terdiri dari:

1. Planning atau perencanaan

2. Acting atau pelaksanaan

3. Observing atau pengamatan

4. Reflecting atau refleksi

Siklus yang berhubungan dengan ke-empat komponen tersebut akan digambarkan dalam bentuk berikut.

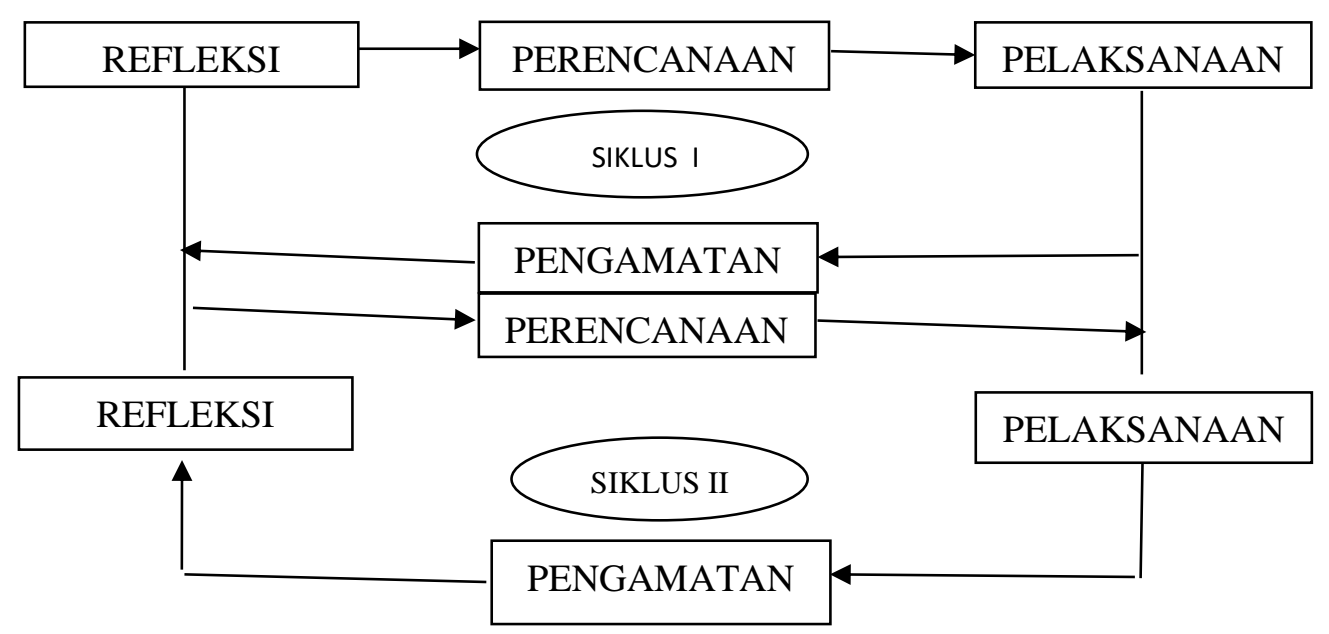

Gambar 1.1 Siklus dalam Penelitian Tindakan Kelas menurut Arikunto (2012:16)

A. Tempat Dan Waktu Penelitian

1. Tempat penelitian

Tempat penelitian adalah tempat yang digunakan dalam melakukan penelitian untuk memperoleh data yang diinginkan. Penelitian ini bertempat di RA ANNUR Wonoayu Sidoarjo.

2. Waktu penelitian

3. Penelitian ini akan dilaksanakan pada semester genap pada kelompok A1 di RA ANNUR Wonoayu Sidoarjo tahun ajaran 2020-2021. Penentuan waktu dalam penelitian akan mengacu pada kalender akademik sekolah karena dalam Penelitian Tindakan Kelas (PTK) akan memerlukan beberapa siklus yang pastinya akan membutuhkan proses belajar yang efektif di dalam kelas. 
B. Subjek Penelitian

Subjek penelitian tindakan kelas untuk meningkatkan kemampuan membaca permulaan melalui media papan lotto yang merupakan salah satu kegiatan dari pembelajaran bermain sambil belajar yaitu peserta didik dari kelompok A1 (usia 4-5 tahun) di RA ANNUR Wonoayu Sidoarjo dengan jumlah siswa 20 anak, yaitu terdiri dari 10 anak laki-laki dan 10 anak perempuan.

C. Prosedur Penelitian

Berdasarkan model penelitian tindakan kelas model Arikunto (2010:16), maka prosedur atau tahapannya yaitu perencanaan, pelaksanaan, pengamatan dan refleksi. Apabila siklus I masih melampaui dalam indikator kerja, maka akan dapat dilakukan perbaikan lagi pada siklus berikutnya hingga target yang dicapai sudah sesuai harapan.

Siklus I :

1. Tahap Perencanaan atau Planning yang terdiri dari :

a. Menyusun Rencana Pelaksanaan Pembelajaran Harian (RPPH) yang sesuai dengan materi yang akan diajarkan.

b. Mempersiapkan sumber dan alat pembelajaran

c. Mempersiapkan instrumen penilaian

d. Menyusun dan mempersiapkan lembar observasi

2. Tahap Pelaksanan atau Acting

Pada tahap ini peniliti melakukan proses pembelajaran berdasarkan RPPH (terlampir) yang telah disusun. Karena permainan papan lotto ini merupakan permainan menggunakan alat sehingga guru memerlukan banyak persiapan dan pelaksanaan permainanpun dapat dilakukan dengan cepat. Adapun cara pelaksanaan permainan ini adalah :

a. Guru menyiapkan alat peraga dan mengatur posisi tempat duduk.

b. Guru menyampaikan materi dan merangsang kemampuan anak membaca permulaan yang akan disampaikan.

c. Guru menunjukkan alat peraga kartu huruf dan gambar agar anak mau memperhatikan.

d. Guru memberi pertanyaan tentang huruf a-z.

e. Guru memberikan kesempatan pada anak untuk mengulang menirukan kembali huruf a-z yang telah di sampaikan.

3. Tahap Pengamatan atau Observasi

Pada tahap ini peniliti melakukan pengamatan atau observasi mengenai proses pelaksanaan pembelajaran yang sedang berlangsung. Pengamatan tersebut dilakukan peneliti diantaranya:

a. Mengamati aktivitas anak dalam proses belajar menggunakan media papan lotto.

b. Mencatat dan mengamati semua peristiwa yang akan muncul, baik yang mendukung maupun yang menghambat dalam proses belajar mengunakan media papan lotto.

4. Tahap Refleksi atau Reflecting

Pada tahap ini peniliti akan merefleksi atau menilai seluruh tindakan yang telah dilakukan berdasarkan pada hasil observasi. Hasil observasi yang telah diperoleh tersebut, selanjutnya akan dianalisa untuk mengetahui tingkat keberhasilan dan mencari apa yang menghambat selama penelitian ini dilaksanakan. Jika ternyata hasil yang diperoleh masih belum mencapai indikator yang telah ditetapkan maka peneliti akan melakukan di siklus berikutnya. 
Siklus II:

Kegiatan ini merupakan kegiatan perbaikan dari siklus I. Tahapan ini sama seperti siklus I yaitu yang diawali dengan perencanaan, pelaksanaan, pengamatan dan refleksi. Peneliti menganalisa hasil observasi yang telah diperoleh. Setelah dianalisa, peneliti menyimpulkan hasil observasi belajar menggunakan media papan lotto.

Perbedaan dari siklus I dan siklus II terletak pada kegiatan pertama atau inti. Dimana dalam siklus I peserta didik diberikan kartu huruf dan gambar yang tidak berwarna. Namun pada siklus II peserta didik lebih diberikan penguatan untuk meningkatkan kemampuan membaca dengan memberikan kartu huruf dan gambar yang berwarna serta membagi peserta didik menjadi 4 kelompok agar lebih tertib dan antusias dalam melakukan kegiatan belajar menggunakan media papan lotto.

D. Teknik Pengumpulan Data

Menurut Sugiyono (2014:308) pengumpulan data merupakan langkah yang paling penting dalam penelitian, karena tujuan utama dari penelitian adalah mendapatkan data. Teknik pengumpulan data yang diambil atau dilakukan oleh peneliti adalah teknik observasi dan dokumentasi. Teknik pengumpulan data tersebut dilakukan oleh peneliti agar mendapatkan data yang valid, maka peneliti melakukan pengumpulan data dengan cara yaitu:

1. Observasi

Sugiyono (2014:204) mengemukakan bahwa, observasi merupakan suatu proses yang kompleks, suatu proses yang tersusun dari pelbagai proses biologis dan psikologis. Dua diantara yang terpenting adalah proses-proses pengamatan dan ingatan. Sugiyono (2014:310) menyatakan bahwa melalui observasi, peneliti belajar tentang perilaku dan makna dari perilaku tersebut. Dari beberapa pengertian diatas dapat disimpulkan bahwa observasi adalah aktivitas terhadap suatu proses atau objek dengan maksud merasakan kemudian memahami pengetahuan dari sebuah fenomena berdasarkan pengetahuan dan gagasan yang sudah diketahui sebelumnya, untuk mendapatkan informasi-informasi yang dibutuhkan untuk melanjutkan suatu penelitian.

\section{Dokumentasi}

Sugiyono (2014:329) mengungkapkan bahwa dokumen merupakan catatan peristiwa yang sudah berlalu. Dokumen bisa berbentuk tulisan, gambar, atau karya-karya monumental seseorang. Menurut Mulyasa (2010:67) dokumentasi adalah instrumen untuk mengumpulkan informasi/data tentang peristiwa yang telah didokumentasikan. Dapat dikatakan juga bahan dokumentasi dapat dijadikan alat untuk menggali data mengenai hal-hal atau variabel yang berupa catatan, transkrip, buku, surat kabar, majalah, prasasti, notulen rapat, agenda dan sebagainya.

Menurut beberapa pengertian diatas dapat disimpulkan bahwa dokumentasi adalah teknik pengumpulan data yang dilakukan dengan cara mengumpulkan data-data dari suatu objek baik melalui catatan, notulen, gambar ataupun video.

E. Instrumen Penelitian

Peneliti akan menggunakan instrumen penelitian sebagai alat untuk mengumpulkan beberapa data yang akan dipergunakan untuk mendukung dalam penelitian ini. Instrumen penelitian ini digunakan untuk mengukur kemampuan membaca permulaan melalui media papan lotto, sesuai dengan indikator. 
HASIL

Tabel 1.1

Rangkuman Hasil Penilaian Rata-rata dan Persentase Pra-Penelitian Indikator Meningkatkan Kemampuan Membaca Permulaan Melalui Media Papan Lotto di RA ANNUR Wonoayu Sidoarjo

\begin{tabular}{|c|c|c|c|c|c|c|c|c|}
\hline No & Indikator penilaian & $\mathrm{X}$ & $\mathrm{F}$ & $\mathrm{N}$ & Persentase & $\mathrm{FX}$ & Rata-rata & Persentase \\
\hline 1 & $\begin{array}{l}\text { Menirukan kembali 3- } \\
4 \text { urutan huruf }\end{array}$ & 4 & $\begin{array}{l}0 \\
1 \\
7 \\
12 \\
\end{array}$ & 20 & $\begin{array}{l}0 \% \\
5 \% \\
35 \% \\
60 \% \\
\end{array}$ & $\begin{array}{l}0 \\
3 \\
14 \\
12 \\
\end{array}$ & 1,45 & $48,33 \%$ \\
\hline 2 & $\begin{array}{l}\text { Menghubungkan } \\
\text { gambar atau benda } \\
\text { dengan huruf A-Z }\end{array}$ & 4 & $\begin{array}{l}0 \\
1 \\
7 \\
12 \\
\end{array}$ & 20 & $\begin{array}{l}0 \% \\
5 \% \\
35 \% \\
60 \% \\
\end{array}$ & $\begin{array}{l}0 \\
3 \\
14 \\
12 \\
\end{array}$ & 1,45 & $48,33 \%$ \\
\hline 3 & $\begin{array}{l}\text { Menyebutkan kata- } \\
\text { kata yang mempunyai } \\
\text { suku kata awal yang } \\
\text { sama }\end{array}$ & 4 & $\begin{array}{l}0 \\
3 \\
4 \\
13\end{array}$ & 20 & $\begin{array}{l}0 \% \\
15 \% \\
20 \% \\
65 \% \\
\end{array}$ & $\begin{array}{l}0 \\
9 \\
8 \\
13 \\
\end{array}$ & 1,5 & $50 \%$ \\
\hline \multicolumn{7}{|c|}{ Hasil rata-rata } & $\begin{array}{l}4,4: 3= \\
1,46\end{array}$ & $48,88 \%$ \\
\hline
\end{tabular}

Berdasarkan grafik tersebut menunjukkan masih rendahnya nilai kemampuan membaca permulaan pada anak. Hal ini diperkuat oleh beberapa temuan kualitatif sebagai berikut :

1. Lebih seringnya melakukan pembelajaran mewarnai sedangkan untuk pembelajaran membaca permulaan dengan menggunakan media papan lotto tidak pernah dilakukan.

2. Pada saat peneliti melakukan observasi awal terlihat ada anak yang masih ditunggu orang tuanya di dalam kelas.

Melalui gambaran hasil penelitian pada pra intervensi tersebut peneliti menyimpulkan bahwa perlu dilakukan perancangan strategi melalui kegiatan media papan lotto pada anak kelompok A1 di RA ANNUR Wonoayu Sidoarjo. Melalui media papan lotto di harapkan dapat membantu memperbaiki dan meningkatkan kemampuan membaca permulaan anak. Rancangan pelaksanaan tindakan ini akan diupayakan dilaksanakan pada siklus 1.

Tahap Siklus I

Pada siklus I dilakukan secara bertahap selama 2 kali pertemuan yaitu pada hari jum'at 11 juni 2021 dan hari sabtu 12 juni 2021. Setiap pertemuan berlangsung \pm 60 menit. Adapun peran penelitian dalam penelitian ini adalah sebagai perancang tindakan dan sebagai pelaksanaan.

a. Perencanaan

Sebelum melakukan tindakan, peneliti mendiskusikan program tindakan yang akan dilakukan.

Selain itu, peneliti menyiapkan RPPM sesuai tema, membuat rencana pelaksanaan pembelajaran harian (RPPH) dan merancang kegiatan yang akan diberikan kepada siswa, 
menyiapkan alat pengumpul data berupa catatan lapangan, menyiapakan alat dokumentasi, berupa kamera dan handycam, membuat lembar pedoman observasi dan mengkondisikan ruang kelas.

b. Pelaksanaan

Pelaksanaan tindakan siklus I dalam upaya meningkatkan kemampuan membaca permulaan melalui media papan lotto pada anak kelompok A1 di RA AN-NUR Pilang Wonoayu Sidoarjo, sebagai berikut :

Guru menunjukkan langkah-langkah permainan, yaitu guru menyiapakan alat peraga, guru menyampaikan materi dan merangsang kemampuan anak membaca permulaan yang akan disampaikan, guru menunjukkan alat peraga, kartu huruf, dan gambar agar anak mau memperhatikan, guru memberi pertanyaan tentang huruf $\mathrm{A}-\mathrm{Z}$, guru memberikan kesempatan pada anak untuk menirukan kembali huruf A-Z yang telah disampaikan. Setelah siswa mengetauhi dan mengerti langkah-langkah pembelajaran media papan lotto, pembelajaran siap dimainkan bersama-sama.

Pada siklus I ini tindakan dilakukan sebanyak 2 kali dengan waktu \pm 60 menit. Pertemuan ini dihadiri oleh peneliti, 2 orang guru kelas, serta 20 anak yang akan diberikan tindakan serta diamati sebagai subjek penelitian. Kegiatan pertama yang dilakukan adalah duduk dilantai menghadap peneliti, kemudian guru mulai mengenalkan media papan lotto dan pembelajaranpun akan dimulai sesuai dengan indikator. Adapun hasil penerapan pembelajaran media papan lotto pada siklus 1 dapat disampaikan dalam bentuk tabel sebagai berikut :

Tabel 1.2

\section{Rangkuman Hasil Penilaian Rata-rata dan Persentase Siklus I Indikator Meningkatkan Kemampuan Membaca Permulaan Melalui Media Papan Lotto di RA ANNUR Wonoayu Sidoarjo}

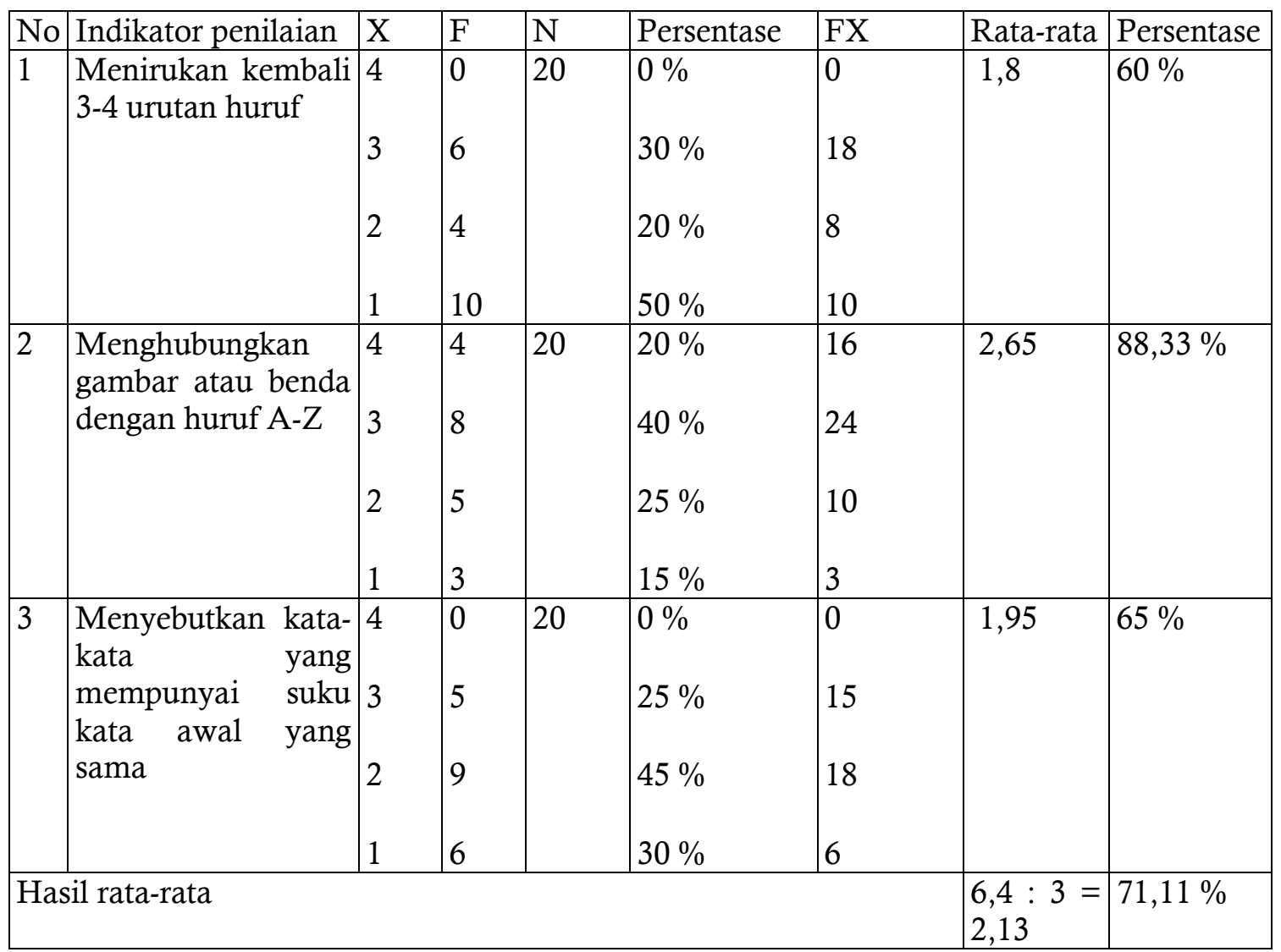


c. Observasi

Pada kegiatan siklus I (tindakan I) anak mulai aktif dan tertarik mengikuti pembelajaran dengan menggunakan media papan lotto untuk meningkatkan kemampuan membaca permulaan pada anak kelompok A1, dan mengenalkan huruf A-Z, anak mulai mampu menghubungkan gambar atau benda dengan kata. Pembelajaran media papan lotto belum pernah dikenalkan pada anak sebelumnya. Pada kegiatan siklus I (tindakan II) anak mulai dapat menyebutkan kata-kata yang mempunyai suku kata awal yang sama dalam pembelajaran media papan lotto dan kemampuan anak membaca permulaan mulai terlihat peningkatan pada beberapa anak.

d. Refleksi

Tahap refleksi yang telah dilakukan peneliti pada akhir siklus I, yakni membaca permulaan dengan media papan lotto belum mencapai indikator kerja yang sudah ditentukan. Dilihat dari ketuntasan kemampuan beberapa indikator belum mencapai $75 \%$ dari seluruh jumlah siswa kelompok A1.

Namun demikian peneliti akan menguji coba kembali penerapan pembelajaran media papan lotto dalam upaya meningkatkan kemampuan membaca permulaan anak kelompok A1 di RA ANNUR Pilang Wonoayu Sidoarjo. Untuk melihat perubahan peningkatan kemampuan membaca permulaan anak yang masih memungkinkan untuk ditingkatkan lebih baik hingga mencapai ketuntasan atau peningkatan $90 \%$ dan pembelajaran membaca permulaan melalui media papan lotto dilanjutkan pada siklus II.

Tahap siklus II

Pada tahap siklus II ini pelaksanaan dilakukan sebanyak dua kali yaitu pada hari senin 14 juni 2021 dan hari selasa 15 juni 2021 untuk menegaskan kembali bahwa, pembelajaran media papan lotto dapat meningkatkan kemampuan membaca permulaan anak kelompok A1 di RA ANNUR Wonoayu Sidoarjo. Karena berdasarkan hasil pelaksaan tindakan siklus I sudah terjadi peningkatan pada lingkup perkembangan bahasa yang salah satu indikatornya adalah menghubungkan gambar. Oleh karena itu pembelajaran yang diajarkan pada siklus II adalah pembelajaran yang sama seperti pada siklus I yakni pembelajaran membaca melalui media papan lotto, jika terjadi peningkatan maka pembelajaran media papan lotto sudah mampu meningkatkan kemampuan membaca permulaan pada anak kelompok A1 di RA ANNUR Pilang Wonoayu Sidoarjo.

Berdasarkan uraian tersebut maka pelaksanaan siklus II dapat dideskripsikan sebagai berikut:

a. Perencanaan

Perencanaan tindakan dilakukan peneliti sesuai dengan langkah-langkah yang dilakukan pada siklus I secara garis besar. Peneliti menyiapkan dan melakukan langkah-langkah pembelajaran sama dengan siklus I.

b. Pelaksanaan

Pelaksanaan pembelajaran siklus II dilaksanakan lebih variatif agar siswa tidak bosan dan semakin aktif seperti anak-anak membuat dua barisan saling berhadapan dengan peneliti berada didepan. Media gambar dibuat berwarna sehingga menarik anak-anak dalam upaya meningkatkan kemampuan membaca permulaan melalui media papan lotto pada anak kelompok A1 di RA ANNUR Wonoayu Sidoarjo.

Penerapan pembelajaran media papan lotto pada siklus II ini dilakukan sebanyak dua kali. Adapun hasil pelaksanaan pembelajaran kemampuan membaca permulaan melalui media papan lotto pada anak kelompok A1 di RA ANNUR dapat ditampilkan dalam bentuk tabel sebagai berikut: 
Tabel 1.3

Rangkuman Hasil Penilaian Rata-rata dan Persentase Siklus II Indikator Meningkatkan Kemampuan Membaca Permulaan Melalui Media Papan Lotto di RA ANNUR Wonoayu Sidoarjo

\begin{tabular}{|c|c|c|c|c|c|c|c|c|}
\hline No & Indikator penilaian & $\mathrm{X}$ & $\mathrm{F}$ & $\mathrm{N}$ & Persentase & FX & Rata-rata & Persentase \\
\hline 1 & $\begin{array}{l}\text { Menirukan kembali 3- } \\
4 \text { urutan huruf }\end{array}$ & 4 & \begin{tabular}{|l|}
5 \\
8 \\
4 \\
3 \\
\end{tabular} & 20 & $\begin{array}{l}25 \% \\
40 \% \\
20 \% \\
15 \% \\
\end{array}$ & $\begin{array}{l}20 \\
24 \\
8 \\
3 \\
\end{array}$ & 2,75 & $91,66 \%$ \\
\hline 2 & $\begin{array}{l}\text { Menghubungkan } \\
\text { gambar atau benda } \\
\text { dengan huruf } A-Z\end{array}$ & 2 & $\begin{array}{l}4 \\
8 \\
5 \\
3\end{array}$ & 20 & $\begin{array}{l}20 \% \\
40 \% \\
25 \% \\
15 \%\end{array}$ & $\begin{array}{l}16 \\
24 \\
10 \\
3\end{array}$ & 2,65 & $88,33 \%$ \\
\hline 3 & $\begin{array}{l}\text { Menyebutkan kata- } \\
\text { kata yang mempunyai } \\
\text { suku kata awal yang } \\
\text { sama }\end{array}$ & 2 & $\begin{array}{l}4 \\
9 \\
5 \\
2\end{array}$ & 20 & $\begin{array}{l}20 \% \\
45 \% \\
25 \% \\
10 \% \\
\end{array}$ & $\begin{array}{l}16 \\
27 \\
10 \\
2 \\
\end{array}$ & 2,75 & $91,66 \%$ \\
\hline \multicolumn{7}{|c|}{ Hasil rata-rata } & $\begin{array}{l}8,15: 3= \\
2,71\end{array}$ & $90,55 \%$ \\
\hline
\end{tabular}

c. Observasi

Pada kegiatan siklus II terjadi peningkatan kemampuan berbahasa dalam membaca permulaan, secara signifikan melalui pelaksanaan pembelajaran media papan lotto. Hal inipun diikuti oleh peningkatan indikator kemampuan bahasa yang lain. Begitupula dalam pelaksanaan pembelajaran media papan lotto pada siklus II anak-anak sudah bisa menirukan huruf A-Z.

d. Refleksi

Berdasarkan penyajian tabel diatas dapat dijelaskan bahwa pada siklus II diperoleh nilai ratarata 2,71 dengan ketuntasan 91\%. Hal tersebut menunjukkan bahwa pada siklus II ada peningkatan yang signifikan.

Dari hasil yang diperoleh peneliti tidak melanjutkan kembali kegiatan pembelajaran membaca permulaan pada siklus berikutnya karena apa yang sudah dicapai dianggap memuaskan. Dengan kata lain tujuan pembelajaran media papan lotto telah meningkatkan kemampuan membaca permulaan pada anak kelompok A1 di RA ANNUR Wonoayu Sidoarjo.

\section{HASIL DAN PEMBAHASAN}

Berdasarkan hasil penelitian yang telah dilakukan kemampuan membaca permulaan pada kelompok A1 di RA ANNUR Wonoayu Sidoarjo telah meningkat dengan menggunakan media papan lotto. Dibuktikan dengan hasil yang telah didapatkan pada tahap pra siklus, siklus I dan siklus II. 


\section{Grafik 4.1 Grafik Nilai Persentase}

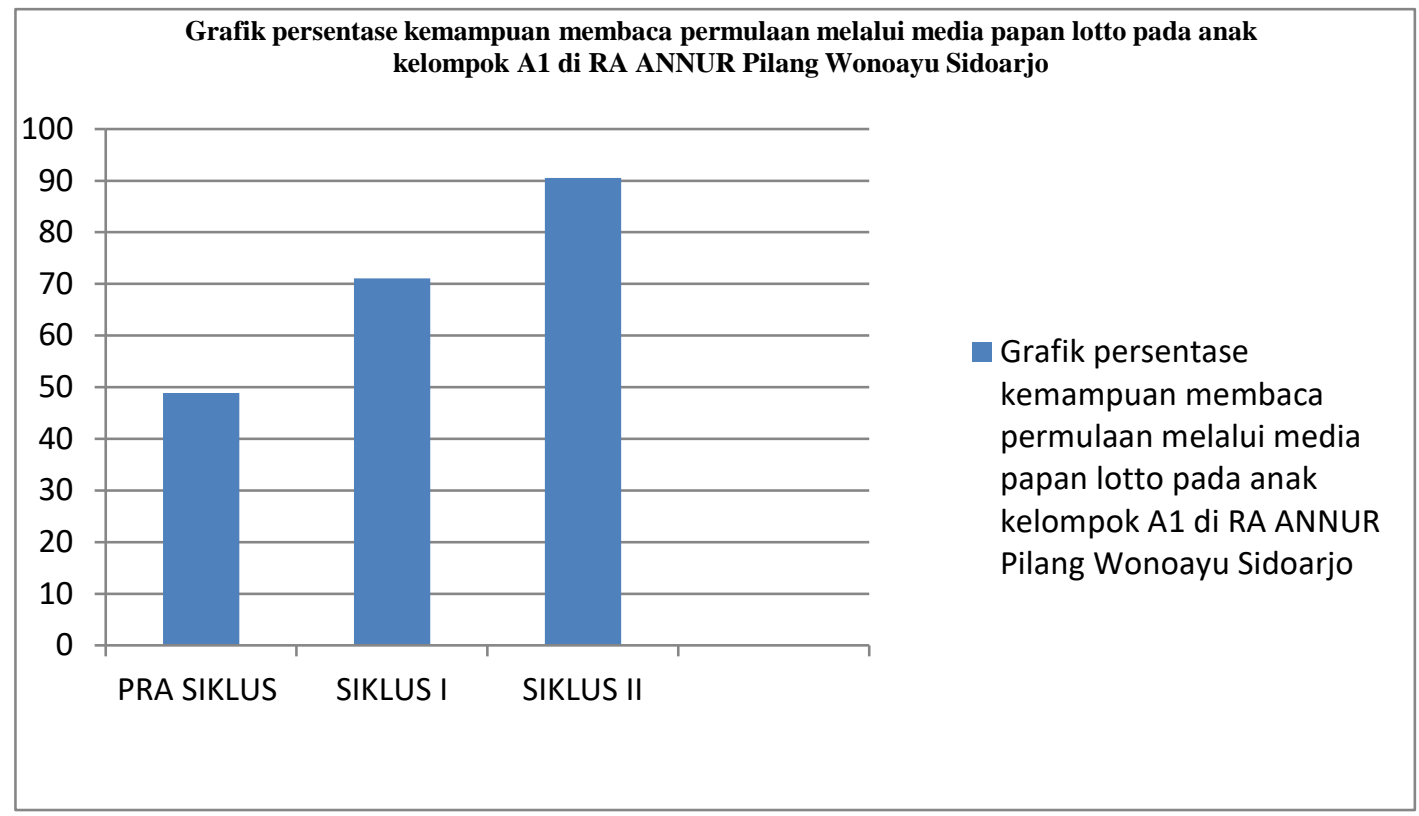

Pada awal tahap pra siklus kemampuan membaca permulaan pada kelompok A1 sebesar 48,8 \% dengan rata-rata 1,46 dengan kriteria (Mulai Berkembang). Kemudian pada siklus I mengalami peningkatan yaitu $71,1 \%$ dengan rata-rata 2,31 dengan kriteria (Berkembang Sesuai Harapan). Selanjutnya pada siklus II mengalami peningkatan signifikan sebesar 90,55 \% dengan rata-rata 2,71 dengan kriteria (Berkembang Sangat Baik). Dengan adanya perkembangan yang signifikan di setiap tahap dan setiap indikator sudah tercapai dengan baik dan secara tidak langsung mengalami peningkatan pada kemampuan siswa yang lain, diantaranya :

1. Mengenal huruf A-Z

2. Kemampuan menyebutkan kelompok gambar yang memiliki bunyi atau huruf

3. Melatih kemampuan bahasa anak

4. Kemampuan mengenal arti kata dari gabungan beberapa huruf konsonan dan vokal

5. Anak-anak menjadi lebih percaya diri

\section{SIMPULAN}

Hasil yang didapat pada penelitian tentang peningkatan kemampuan membaca permulaan melalui media papan lotto pada kelompok A1 di RA ANNUR Wonoayu Sidoarjo, dapat disimpulkan sebagai berikut: Penerapan membaca permulaan pada peserta didik diterapkan menggunakan media "papan lotto". Metode tersebut sanngat efektif untuk diterapkan di RA ANNUR Wonoayu Sidoarjo melihat dari hasil antusiasnya peserta didik dalam kemampuan membaca permulaan setelah diterapkannya media papan lotto ini. Meningkatnya kemampuan membaca permulaan setelah diadakan penelitian ini yaitu sebelumnya hanya $48,8 \%$ anak yang mampu membaca menjadi $90,5 \%$ anak yang mampu membaca permulaan dengan media papan lotto. Peneliti dan guru kelas bisa memperhatikan setiap kemampuan yang terdapat pada diri peserta didik. Hal ini dapat dilihat dari perbandingan hasil pra-siklus, siklus I dan siklus II yang hasilnya mempengaruhi peningkatan yang ditunjukkan dengan ketercapaian indikator keberhasilan peneliti. Pada awal tahap pra siklus kemampuan membaca permulaan pada kelompok A1 sebesar 48,8 \% dengan rata-rata 1,46 dengan kriteria (Mulai Berkembang). Kemudian pada siklus I mengalami peningkatan yaitu $71,1 \%$ dengan rata-rata 2,31 dengan kriteria (Berkembang Sesuai Harapan). Selanjutnya pada siklus II mengalami peningkatan signifikan sebesar 90,55 \% dengan rata-rata 2,71 dengan kriteria (Berkembang Sangat Baik). 


\section{DAFTAR PUSTAKA}

Aksara (2019) Jurnal Bahasa dan Sastra. Vol.20, No.1, Hal 10-24 http://iurnal.fkip.unila.ac.id/index.php/aksara desember 2020

Arikunto Suharsimi, Suharjono, Supardi (2006). Penelitian Tindakan Kelas. (Jakarta: Bumi Aksara)

Arikunto Suharsimi et.al (2007). Penelitian Tindakan Kelas. (Jakarta:Bumi Aksara)

Bungin, Burhan. (2013). Penelitian Kualitatif. (Jakarta: Prenada Media Group)

Depdiknas (2010), Pedoman Pengembangan Program Pembelajaran di Taman Kanak-Kanak. (Jakarta)

E. Mulyasa (2010) Praktek Penelitian Tindakan Kelas (Bandung:PT Remaja Rosdakarya Offset)

Maimunah Hasan (2012). Pendidikan Anak Usia Dini. (Jogjakarta:Diva Press Anggota IKAPI)

Nurbaeni Dhieni,dkk (2009). Metode Pengembangan Bahasa. (Tangerang Selatan: Universitas Terbuka)

Nurbiana Dhieni,dkk (2013). Metode Pengembangan Bahasa. (Tangerang Selatan: Universitas Terbuka)

Ni Putu Laris, I Wayan Suwarta, Luh Ayu Tirtayani (2014) .Pemanfaatan Media Papan Lotto Untuk Meningkatkan Perkembangan Kognitif Anak Kelompok A di Paud Santi Kumara.Vol.2, No.1, Tahun 2014

https://eiournal.undiksa.ac.id/index.php/JJPAUD/article/download/3526/2845 desember 2020

Sugiyono (2014). Metode Penelitian Pendidikan. (Bandung:Alfabeta)

Susanto Ahmad, 2011. Perkembangan Anak Usia Dini. Jakarta : Kencana Prenada Media Group.

Sa'dun Akbar (2009) Penelitian Tindakan Kelas, Filosofi dan Implementasi (Yogyakarta: Cipta Media Angkasa)

Sujiono, Y.N. (2009), Konsep Dasar Pendidikan Anak Usia Dini (Jakarta: Kencana) 